\title{
MYCOBACTERIUM AVIUM SUBSPECIAE PARATUBERCULOSIS IDENTIFICATION IN MILK BY MEANS OF IS900 PCR
}

\author{
Fatmira Shehu ${ }^{1}$, Bizena Bijo ${ }^{1}$, Angela Di Pinto ${ }^{2}$, Giancarlo Bozzo ${ }^{2}$ \\ ${ }^{1}$ Faculty of Veterinary Medicine, Agriculture University of Tirana, Albania \\ ${ }^{2}$ Dipartimento di Sanità e Benessere degli Animali, Università degli Studi, Bar, Italy \\ fatmira_shehu@yahoo.it
}

\begin{abstract}
Between the numerous emerging pathogens, Mycobacterium avium subsp. paratuberculosis (MAP) reports a primary interest in its detection for its possible correlation with Crohn's Disease in man (5). Milk and its subproducts may be very important in transmitting Mycobacterium avium subsp. paratuberculosis. The potential sanitary risk is related to the germ capacity in surviving to routine pasteurization treatments (1). These study objectives were the determination and the optimization of DNA extraction and purification assays to the direct Mycobacterium avium subsp. paratuberculosis (MAP) detection in milk, by means of PCR. The obtained results with the applied method are based in the milk and its subproducts chain inspective and control actions, relating to the increasing paratuberculosis etiological agent presence and the potential zoonotic transmitting.
\end{abstract}

Key words: Mycobacterium avium subsp. paratuberculosis (MAP); milk; PCR; SPF (Specific Pathogen Free)

\section{ИДЕНТИФИКАЦИЈА НА МYСОВАСТЕRIUM AVIUM SUBSPECIAE PARATUBERCULOSIS ВО МЛЕКОТО СО ПОМОШ НА IS900 PCR}

\begin{abstract}
Meѓy бројните откриени патогени, Mycobacterium avium subsp. paratuberculosis (MAP) има примарно значење за неговата детекција поради неговата можна поврзаност со Кроновата болест кај луѓето. Млекото и млечните производи можат да бидат многу важни во пренесување на Mycobacterium avium subsp. paratuberculosis. Потенцијалниот здравствен ризик е поврзан со способноста на оваа бактерија за преживување на рутинските третмани на пастеризација. Предмет на оваа студија е преку екстракцијата и прочистувањето на DNA со помош на PCR директно да се открие Mycobacterium avium subsp. paratuberculosis (MAP) во млекото. Резултатите добиени со применетиот метод се базирани на акциите на инспекција и контрола на млекото и млечните производи, поврзано со зголеменото присуство на паратуберкулозниот етиолошки агенс и потенцијалната зоонотска трансмисија.
\end{abstract}

Клучни зборови: Mycobacterium avium subsp. paratuberculsis (MAP); млеко; PCR, SPF (Specific Pathogen Free)

\section{INTRODUCTION}

Johne's disease, caused by Mycobacterium avium subsp. paratuberculosis (MAP), is a chronic granulomatosis infection of the intestinal tract of wild and domestic ruminants. The symptoms of this disease include diarrhea, reduced milk production, emaciation, and ultimately death in infected animals, and infections result in significant economic losses for individual farms and the dairy industry, worldwide.

A traditional "gold standard" testing method for Johne's disease (MAP infection) is the fecal culture. But this method is time-consuming, requires a long incubation period of 8 to more than 16 weeks for bacterial recovery. Because of these difficulties, several PCR tests have been developed to detect MAP $[4,8]$. Although these assays offer the benefits of sensitivity and speed, they cannot 
distinguish between viable and nonviable MAP cells. Clinical similarities have been observed between Johne's disease in cows and Crohn's disease in humans, and both viable MAP and MAP genetic material have been found in some patients diagnosed with Crohn's disease [4, 5, 10]. However, no cause and effect relationship between MAP and Crohn's disease has been defined and no documentation proving zoonotic transmission from a cow to a human has been recorded [15]. If there is a causal relationship between MAP and Crohn's disease, investigations into possible vectors through which MAP is spread should provide useful information. Cattle infected with MAP can shed live organisms in their milk [13]. Some researchers have demonstrated that MAP is not able to survive commercial pasteurization [13] or have been critical of the differing pasteurization methodologies used [10], whereas other researchers have found that this organism can survive pasteurization under conditions simulating those used in commercial facilities [2, 5].

\section{MATERIALS AND METHODS}

Sample preparation. - This method optimizing consists in SPF (Specific Pathogen Free) milk used originating from Paratuberculosis free farms, which previously have been surveyed by periodic ELISA tests and cultural examinations. Logarithmic dilutions of the Mycobacterium avium subsp. paratuberculosis strain were performed starting on a solution containing $10^{5}$ mycobacterium $/ \mathrm{ml}$ of each diluted sample an equal amount $(500 \mu \mathrm{l})$ was used for the $4.5 \mathrm{ml}$ SPF full milk experimental contamination.

DNA extraction and purification. - DNA extraction and purification was realized switching up to the Dneasy Tissue Kit (QIAGEN, Hilden, Germany). The indicated protocol from the producer company was modified at the amount of the starting sample, buffers time and the rinses number. The milk amount $(5 \mathrm{ml})$ experimentally contaminated was mixed with $2.5 \mathrm{ml}$ Lysis Buffer ATL and with $250 \mu \mathrm{K}$ Proteinase $(20 \mathrm{mg} / \mathrm{ml})$. After the overnight incubation at $56^{\circ} \mathrm{C}$ in shaking conditions, were proceeded adding $2.5 \mathrm{ml}$ Buffer $\mathrm{AL}$ and then passing to another thermal treatment at $71^{\circ} \mathrm{C}$ for $1 \mathrm{~h}$. The mixed product, with $2.5 \mathrm{ml}$ absolute ethanol, was passed to QIAamp spin col- umn in various centrifugation cycles at 13000 rounds per $1 \mathrm{~min}$. The absorbed DNA in silica gel QIAamp membrane, was submitted to Buffer $\mathrm{AW}_{1}$ and Buffer $\mathrm{AW}_{2}$ washes. At last, the DNA was diluted with $80 \mu \mathrm{l}$ Buffer AE.

IS900-PCR. - Extracted DNA amplification was evaluated by means of PCR, performed on a final volume of $25 \mu$ l, using 12,5 $\mu$ l HotStarTaq Master Mix 2X (QIAGEN, Hilden, Germany) and the content of $0.125 \mu \mathrm{M}$ Primer oligonucleotids, as described by [11]. The amplification program predicted an initial denaturizing at $95^{\circ} \mathrm{C}$ for $15 \mathrm{~min}$, followed by 35 denaturizing cycles at $94^{\circ} \mathrm{C}$ for 30 sec, annealing at $54^{\circ} \mathrm{C}$ for $30 \mathrm{sec}$ and by extension at $72^{\circ} \mathrm{C}$ for $45 \mathrm{sec}$. The reaction was realized on a Mastercycler personal (Eppendorf, Milano, Italia). Amplifications specificity was insured by the enzymatic dissolution using MseI [9]. Amplification products were analyzed by means of electrophoresis on agarose gel and were visible by ethid bromurium coloring.

\section{RESULTS AND CONCLUSIONS}

The individualized nucleic acids extraction and the purification method, based on the use of $\mathrm{K}$ proteinase and silicium filter tubes, randomly applied for full fat milk analyzing has insured the complete sample dissolution and has demonstrated an easy execution. This system also brought out amplified DNA, ensuring so the vantage of an appropriate target molecules number and of the inhibitors removal. In fact, PCR-IS900 used for the verification of the extracted and purified DNA amplification based on experimentally contaminated milk portions with logarithmic dilutions of M. avium subsp. paratuberculosis, evidenced a limit of the revelation (LOD) equal to 10 organisms for $\mathrm{ml}$. The analysis revealed the expected results as previously described by Khare et al. [9] (2004). The described extracting procedure is demonstrated as widely applicable for the $\mathrm{Myco-}$ bacterium avium subsp. paratuberculosis identification in the unelaborated milk by means of PCR. Comparing to the immune - magnetic division, widely used for the Mycobacterium avium subsp. paratuberculosis detection, in various types of food samples $[9,7,14]$, the above described procedure results less costly and laborious. This method also consists in short times performances, 
an aspect not to be unconsidered for its importance on the experimental definition of the analytical control strategies. The obtained results with the proposed method are in concordance with the inspective action and with the milk chain control and its subproducts, as the interests to face the paratuberculosis (PTB) etiological agent are increasing, and as the zoonotic potential still unknown can be detected emergently.

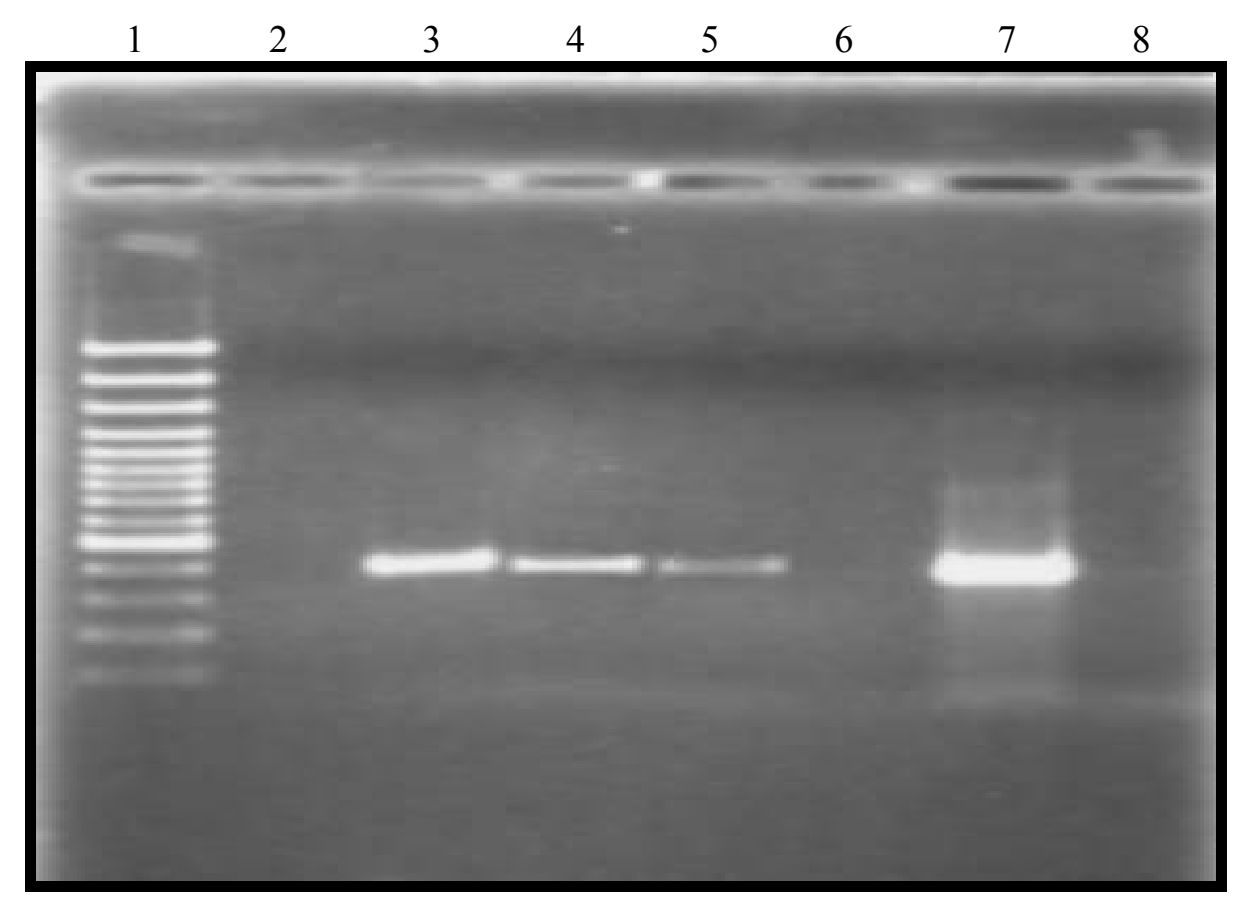

Fig. 1. Electrophoretic profile obtained by experimentally contaminated milk with logarithmic dilutions with Mycobacterium avium subsp. paratuberculosis (400 bp).

Lane 1: 100 pb DNA Ladder;

Lane 2: negative control sample (DNA Mycobacterium avium subsp. avium);

Lane 3: 103 mycobacteriums $/ \mathrm{ml}$;

Lane 4: 102 mycobacteriums $/ \mathrm{ml}$;

Lane 5: 10 mycobacteriums $/ \mathrm{ml}$;

Lane 6: $<10$ mycobacteriums $/ \mathrm{ml}$;

Lane 7: positive control sample (Mycobacterium avium subsp. paratuberculosis);

Lane 8: negative reagent (no $\mathrm{ADN}$ )

Acknowledgments. The authors thank Prof. Dr. M. G Tantillo. and Dr. Novello L. (Dipartimento di Sanita e Benessere degli animali, Facolta di Medicina Veterinaria, Universita di Bari, Italy) for their great support on this study.

\section{REFERENCES}

[1] Chamberlin, W., D. Y. Graham, K. Hulten, H. M. T. ElZimaity, M. R. Schwartz, S. Naser, I. Shafran, F. A. K. El-Zaatari (2001): Review article: Mycobacterium avium subsp. paratuberculosis as one cause of Crohn's disease. Aliment. Pharmacol. Ther. 15: 337-346.
[2] Chiodini, R. J. and J. Hermon-Taylor (1993): The thermal resistance of Mycobacterium paratuberculosis in raw milk under conditions simulating pasteurization. J. Vet. Diagn. Invest. 5: 629-631.

[3] Collins, M. T., G. Lisby, C. Moser, D. Chicks, S. Christensen, M. Reichelderfer, N. Hoiby, B. A. Harms, O. O. Thomsen, U. Skibsted, and V. Binder (2000): Results of multiple diagnostic tests for Mycobacterium avium subsp. paratuberculosis in patients with inflammatory bowel disease and in controls. J. Clin. Microbiol. 38: 43734381.

[4] Ellingson, J. L., C. A. Bolin, and J. R. Stabel (1998): Identification of a gene unique to Mycobacterium avium subspecies paratuberculosis and application to diagnosis of paratuberculosis. Mol. Cell. Probes, 12: 133-142. 
[5] Grant, I. R., H. J. Ball and M. T. Rowe. (1998): Effect of high temperature, short time (HTST) pasteurization on milk containing low numbers of Mycobacterium paratuberculosis. Lett. Appl. Microbiol. 26: 166-170.

[6] Grant I. R., A. G. Williams, M. T. Rowe, D. D. Muir (2005): Efficacy of various pasteurization time-temperature conditions in combination ëith homogenization on inactivation of Mycobacterium avium subsp. paratuberculosis in milk. Appl. Environ. Microbiol. 71: $2853-$ 2861.

[7] Grant I.R., C. Pope, L. O'riordan, H. Ball, and M. Rowe (2000): Improved detection of Mycobacterium avium subsp. paratuberculosis in milk by immunomagnetic PCR. Vet. Microbiol. 77: C., 369-378.

[8] Green E. P., M. L. Tizard, M. T. Moss, J. Thompson, D. J. Winterbourne, J. J. Mcfadden, and J. Hermon-Taylor. (1989): Sequence and characteristics of IS900, an insertion element identified in a human Crohn's disease isolate of Mycobacterium paratuberculosis. Nucleic Acids Res. 22: 9063-9073.

[9] Khare S, T. A Ficht, R. L Santos, J Romano, A. R Ficht, S Zhang, I. R Grant, M. Libal, D. Hunter, L. G. Adams (2004): Rapid and sensitive detection of Mycobacterium avium subsp. paratuberculosis in bovine milk and feces by a combination of immunomagnetic bead separationconventional PCR and real-time PCR. J. Clin. Microbiol. 42: 1075-1081.

[10] Lund, B. M., G. W. Gould and A. M. Rampling (2002): Pasteurization of milk and the heat resistance of $\mathrm{Myco-}$ bacterium avium subsp. paratuberculosis: A critical review of the data. J. Food Prot., Vol. 68, No. 5, Int. J. Food Microbiol. 77: 245.

[11] Sanderson J. D., M. T Moss., M. L.Tizard, And HermonTaylor J.. (1992): Mycobacterium paratuberculosis DNA in Crohn's disease tissue. Gut, 33: 890-896.

[12] Sechi L. A., A. M. Scanu, P. Molicotti, S. Cannas, M. Mura, G Dettori., G. Fadda, and S. Zanetti (2005): Detection and isolation of Mycobacterium avium subspecies paratuberculosis from intestinal mucosal biopsies of patients with and without Crohn's disease in Sardinia. Am. J. Gastroenterol. 100: 1529-1536.

[13] Stabel J. R., E. M.Steadham, and C. A. Boli (1997): Heat inactivation of Mycobacterium paratuberculosis in raw milk: Are current pasteurization conditions effective? Appl. Environ. Microbiol. 63: 4975-4977.

[14] Whan L., H. J. Ball., I. R Grant., M. T Rowe (2005): Development of an IMS-PCR assay for the detection of Mycobacterium avium subsp. paratuberculosis in water. 40: 269-273.

[15] Van Kruiningen, H. J. (1999): Lack of support for a common etiology in Johne's disease of animals and Crohn's disease in humans. Inflamm. Bowel Dis. 5: 183191. 